\section{Hungary: academy is not obsolete or discriminatory}

SIR - We were puzzled by your News story

"Hungary's science academy slammed as 'obsolete'” (Nature 441, 1034-1035; 2006), because we had previously provided you with information that contradicts it. Contrary to your story and the statements made by people cited in it, our academy does not discriminate against scientific achievement obtained outside Hungary.

To cite the relevant part of our byelaws when conferring a Doctor of Science (Doctor of the Academy) title, from the www.mta.hu website: "When evaluating results arising from research done in an advanced industrial country, articles can be included fully in the impact factor total only if the applicant is the first or last mentioned co-author. If not, articles can be included in the impact factor or citation index total only to the effect of $25 \%$. If the applicant competes for a Doctor of the Academy title on the basis of research done in a foreign country scientifically as advanced as Hungary, or less advanced than Hungary, reaching the domestic minimal measure is the minimal condition of allowing him/her to compete for the title."

By quoting people who call the Hungarian Academy of Sciences "obsolete" you are unjustly offending almost two-thirds of its members, and indeed three-quarters of our Doctors of the Academy, elected after 1990, not to mention more than half the academy's research staff, who started their scientific careers after that date.

We are troubled that you ignored the information we provided to your reporter before the article was published, and instead featured overwhelmingly the views of people who had previously denounced the academy and the scientific community in Hungary, and had met with rebuttals. We find your News story tendentious and partial, at odds with Nature's widely respected objectivity and editorial integrity .

\section{György Fábri}

Communications and Science Policy,

The Hungarian Academy of Sciences,

Roosevelt sq. 9, H-1051 Budapest, Hungary

\section{Hungary: academy needs more than internal reform}

SIR - Your News story "Hungary's science academy slammed as 'obsolete" (Nature 441, 1034-1035; 2006) describing some of the practices of the Hungarian Academy of Sciences, with respect to the requirements for its doctoral degree, only touches the tip of the iceberg. There are many chronic problems with the academy (see Nature 427, 94-95, 2004), such as the ageing leadership, lifelong tenure and funding allocations heavily favouring academy members and their institutions.

Although I did, as your News story reported, return to Hungary after 10 years of working in the United Kingdom and the United States, I stayed for only one year because of these outdated practices. I called for an internationally competitive sciencemanagement system and spoke out against the state-funded privileges and the lifelong compensation system the members of the academy enjoy. Two days later, I was told by the head of my department at Semmelweis University to look for another job.

A radical change in Hungarian science administration is overdue. The recent removal of the criticized sections from the academy's webpage is not going to change anything. I seriously doubt that the new 'internal reform committee' of the Hungarian Academy of Sciences is what the country needs.

\section{Csaba Szabo}

Department of Surgery, University of Medicine and Dentistry of New Jersey, Newark,

New Jersey 07103, USA

\section{Quest for seed immortality is mission impossible}

SIR - In your News story "Doomsday food store takes pole position" (Nature 441, 912-913; 2006) you report the establishment of a "doomsday seed bank from which the genetic riches of Earth's food crops could, if necessary, be reconstituted". Unfortunately, this statement is wishful thinking.

As managers of one of the largest ex situ gene banks in the world, we have been surprised during the past few weeks by the increased number of comments by visitors about the possibility of seeds being kept viable for millennia if stored at sufficiently low temperatures. There are very few reported cases in which seeds were able to germinate after many decades or even more than a century of storage: most cannot survive long-term storage.

One prominent example is provided by a herbarium sample of the legume Albizzia julibrissin, which had been collected in China in 1793 and was deposited in the British Museum. The material was accidentally wetted in 1940 during firefighting, resulting in the germination of several seeds at least 147 years old (Nature 149, 658; 1942). There are a few other documented examples where seeds have been able to germinate after 100 years (details available on request from the authors), but these are rare exceptions. The suggestion that seeds can survive after thousands of years is wrong, and detrimental to conservation funding efforts.

Undoubtedly, it is important to keep safety duplicates for the estimated 6 million seed samples that are kept in ex situ gene banks worldwide. To this end, the food store featured in your News story is an important contribution. But the vast majority of plant seeds cannot be stored for more than 40 years without losing germination vigour, however low the temperature and however thick the concrete walls of the vault. Hence, gene banks have no other choice but to preserve their material by growing plants in greenhouses, field plots or in laboratories at regular intervals. This process requires manpower, knowledge and rigorous quality management. It is also the bottleneck in almost all the gene banks so far established: the seeds they contain urgently require regeneration, otherwise they will die.

Andreas Graner, Andreas Börner

Federal ex situ Genebank, Leibniz Institute of Plant Genetics and Crop Plant Research, 06466 Gatersleben, Germany

\section{No place for secrets in scientific research}

SIR - I heartily endorse the call in your Editorial "Illuminating the black box" (Nature 442, 1; 2006) for transparency in describing materials and reagents used in scientific papers. As editor-in-chief of the Journal of Comparative Neurology, one of the largest and oldest neuroscience journals, I have for some time required authors to provide full information on the origin and specificity of all reagents, especially antibodies (C. B. Saper and P. E. Sawchenko J. Comp. Neurol. 465, 161-163; 2003).

In addition to the criteria raised in your Editorial, for "specificity and utility" of an antibody, the chemical structure against which the antibody was raised must be known for an experiment to be replicable. Commercial availability of a reagent does not satisfy this need, as the manufacturer may change the nature of a reagent, or go out of business. Many commercial firms have taken to declaring the chemical structure against which the antibody was raised as 'proprietary', in other words, a trade secret. I tell authors that 'proprietary' is another term for 'not fit for serious scientific work', and our journal will not publish work that is done with such reagents.

I applaud Nature for insisting on full disclosure about reagents. It will be hard work to implement these policies, as many reviewers are not yet sufficiently aware of or concerned by this issue, but the integrity of science depends on it.

Clifford B. Saper

Department of Neurology and Program in

Neuroscience, Harvard Medical School, and Beth Israel Deaconess Medical Center, Boston, Massachusetts 02215, USA 